ARTICLE

https://doi.org/10.1057/s41599-020-0488-2

\title{
OPEN
}

\section{Unfolding unpaid domestic work in India: women's constraints, choices, and career}

\author{
Pushpendra Singh (10) ${ }^{1 凶} \&$ Falguni Pattanaik ${ }^{1}$
}

\begin{abstract}
Unpaid domestic work is an important aspect of productive activities and an indispensable factor that contributes to the well-being of household and economy. However, the predominance of women in domestic work and keeping them out of 'economic activities' put unpaid domestic work under the shadow of invisibility, outside the production boundaries, and further outside the purview of economic policy. The nature of women's work has endured substantial alterations during the neo-liberal paradigm of Indian economy, and women's participation in the labor force and workforce has declined significantly. To understand the status of women in the labor market, it is necessary to comprehend the nature of their unpaid work, which has significant impact on their work participation rate in the economy. Therefore, the objective of this study is to examine the magnitude and factors that influence the unpaid domestic work status of women in India. The findings of this study reveal that the intensity to be engaged in domestic work is high among women who are less educated and belong to the lower wealth quintile in society. Women are engaged in unpaid domestic work because of three factors-Constraints (social and religious), Choices (failure of market and states to provide essential provisioning), and Career (low opportunity cost of unpaid work in the market). Therefore, a holistical approach within the broader context of household, state, market, and society through a macro, meso, and micro interconnects has to be considered for changing women's status in the economy.
\end{abstract}

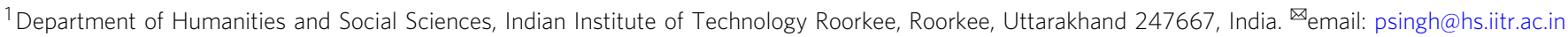




\section{Introduction}

npaid work is an important aspect of economic activity and is indispensable for the well-being of individuals, households, and in fact, for the economy as a whole. Nevertheless, the economic analyses and policy formulations have neglected unpaid work be it in the form of economic production of goods for self-consumption or services enjoyed by others in the household. However, in the late 1960s attempts have been made by feminist economists to incorporate women's domestic labor into the domain of economics and to analyze it as a form of work comparable to paid work (Mincer, 1962; Becker, 1965; Benston, 1969; Dalla Costa and James, 1975; Harrison, 1973; Gardiner et al., 1975). These analyses have a number of diverse aims, which are to recognize the domestic activities within the household carried out by women and value it, to elucidate that women are not present in the labor market not because of their personal choice but due to the economic disadvantage and low opportunity cost and so on (Folbre and Yoon, 2008). All these have a common objective, i.e., to give value and make visible the contribution of women in the household in the form of unpaid domestic activities by recognizing their effort as work.

The discourse on women's unpaid work is exclusively pertinent in the Indian context because women's labor force participation rate is very low and has seen a declining trend over the last decade probably because majority of them are moving into the domain of 'domestic duties' (Fletcher et al., 2017). In a country like India, merely 22 percent of women are engaged in workforce, and out of them, 70 percent are associated with the farm activities that are informal in nature with little or no economic remuneration or social recognition and almost zero access to social protection (Mehrotra et al., 2014). Most of women's unpaid work is characterized as informal, invisible, and unrecognized in the economy. Further, the marginalization of women in workforce is intensified because of their socioeconomic position in society to carry out unpaid household activities in the family in the form of cooking, cleaning, fetching food, water, and firewood and giving care (Crow and McPike, 2009; Patel et al., 2016). Furthermore, the burden of unpaid work is fortified by the lack of adequate public provisioning in critical sectors, such as energy, health, water and sanitation, food security, and livelihoods (Hirway, 2015). On an average, across the globe, men spent $83 \mathrm{~min}$ in unpaid domestic work while women spent $265 \mathrm{~min}$, i.e., more than three times the time spent by men. However, in India, women spend around $297 \mathrm{~min}$, whereas only $31 \mathrm{~min}$ are spend by men in domestic work (Addati et al., 2018). This gender segregation in unpaid domestic duties reflects a set of social norms and perceptions regarding a "natural" household division of labor and the macroeconomic policies and strategies that do not acknowledge the existence of unpaid domestic work, rather intensify the increase of the burden in the economy (Dong and An, 2015).

Consequently, to understand women's unpaid work in a developing country like India, there is need of analyzing the complex paid-unpaid scale at numerous interrelated levels. The goal of this study is to understand the dynamics of unpaid domestic work by reviewing the existing literature on women's disproportionate share of unpaid work. The objective is to perceive the underlying factors responsible for unpaid domestic work in the presence or absence of enabling conditions, such as societal norms, caste, work condition, educational status, economic status, type of domestic works, and the allocation of time among a range of unpaid activities. The questions that motivated the exploration of the dynamics of women labor in relation to unpaid domestic work status in India are the following: What exactly is unpaid domestic work and its quantum? What are the causes of women to be engaged in unpaid domestic work, and why is it not shrinking as prefigured by standard theories of economic development? Is the issue of women's unpaid domestic work being a matter of decision, choice, or constraint?

The study consists of six sections, including the "Introduction". A brief review of the literature on the issue of unpaid domestic work as a matter of constraint, choice, and career for women has been summarized under section "Unpaid work: theoretical underpins and empirical perspective". The data source, concept, and the methodology of the study are discussed in section "Concepts, database, and methodology". The magnitude of unpaid domestic work and the reason behind its increase among women along with assessing the relative contributions of various dimensions in India (socio-economic and demographic) have been discussed in section "The magnitude of women unpaid domestic activity in India". The consequences of rising unpaid domestic work have been assessed and discussed in section "Assessment of the relative contributions of factors affecting women in domestic duties". Further, in this section of study shows an association between unpaid domestic work and social status, especially for women having low income, low educational status, and belonging to a marginal section of the society. Finally, section "Conclusion" concludes by pulling together all the threads and summarizing the main findings and policy messages.

\section{Unpaid work: theoretical underpins and empirical perspectives}

'Unpaid Work' has not been acknowledged as a part of the mainstream economy under different economic theories. Both the Classical and Neo-classical economists have considered unpaid work not as an economic good or market good thereby keeping it outside the production frontier. Furthermore, while compiling national income accounts, Kuznets (1948) also kept unpaid work outside the purview of national income, as it is part of "housewives' production" and is therefore not a part of the economy. However, in the 1960s, feminists (Benston, 1969; Dalla Costa and James, 1975; Oakley, 1974) perceived that much of the time spent by women on domestic activities is related to "work" and not leisure. In the same time, mainstream economists commenced to augment the conceptions of "work" for inclusion of household activities/work (Mincer, 1962; Becker, 1965; Harrison, 1973; Gardiner et al., 1975). Historically, feminism epitomizes different stages in the process of the breakdown of the sexual division of labor by calling housework as "work". The sexual division of labor is the division of economic and social activities between the sexes. The process of the breakdown of the sexual division of labor can be explained in three stages, i.e., "gender polarization", "gender freedom", and "gender integration" (Matthaei, 2001). In the stage of gender polarization, the division of labor is rigid, where paid work is assigned to men and unpaid work in the household to women (Gilman, 1998; Cott, 1997; Hartmann, 1976; Dubbert, 1979; Cooper et al., 2013). In the second stage of gender freedom, women enter into paid work along with unpaid work. During the early 1970s, feminists focused on the critique of rigid gender roles and claimed that men and women are equal in their abilities, therefore, they should get equal opportunities to work in the paid work previously reserved for men (Kessler-Harris, 1987; Williams, 2001). In the third stage, gender integration, both men and women begin to endeavor for integrating paid and unpaid work (Williams, 2001). In this integrative process, these stages are interlinked with each other. The forces instigating the rise and fall of each stage are complex. The timeline movement of this sexual division of labor from one stage to another will vary for different economies because it is influenced by race, class, ethnicity, 
transfer of technology, capitalist competition, etc. (Amott and Matthaei, 1996).

Over a period of time, attempts have been made to incorporate women's domestic labor into the domain of economics as well as to analyze it as a form of work comparable with paid work. Considering that domestic activities constituted a form of "work", the three different facets having their own insinuation for the position of women's work in the household have been observed. First, household works take time and energy for a purpose and therefore have an opportunity cost, which encourages recognition of these activities as works. Second, women doing housework contribute to the division of labor both at the household and at the societal levels; hence, their work must be reduced. Third, domestic work is separable from the worker and could be done by others; therefore, unpaid domestic work should be redistributed between men and women. The triple " $R$ " (recognition, reduction, and redistribution) approach attempts to integrate unpaid work into the mainstream economy by reducing it and by re-organizing it between the paid and unpaid work (Elson, 2017). Institutions such as state, market, society should work in a comprehensive manner to 'recognize', 'reduce' and 'redistribute' the burden of unpaid work of women within the household.

The sustainable development goals (SDG) recognize the importance of unpaid care and domestic work through public services, infrastructure, and social protection policies as well as shared responsibility within the household (Target 5.4). Therefore, by performing these unpaid works, women subsidize the market and also reduce the burden of the State (Hirway, 2015). However, much of women's unpaid work is unrecognized, unreported, and underestimated by the family, market, and state regardless of the benefits relished by these institutions. Furthermore, neo-liberal macroeconomic policies have been formulated without recognizing, reducing, and redistributing unpaid work in the economy not only to increase forfeit on women but also to have an adverse impact on the economic development (Hirway, 2005; Elson, 2017; Folbre and Yoon, 2008). This lack of recognition increases hierarchy in gender relations and gender inequalities in the family as well as in the economy.
Unpaid domestic work: women's constraints, choices, and career. Most of the unpaid work is not a matter of choice for women; rather, it is a constraint by society and patriarchal norms that women are expected to carry responsibility for work at home. It impedes entry into the labor market and restricts women's income and earning potential (Kabeer, 2012). Therefore, it costs the loss of income and financial independence for women. Further, the inadequate decent employment opportunity in paid work for women increases the incidence of unpaid works and reduces the opportunity cost (Maloney, 2004; Razavi, 2007). Therefore, low female participation acts as disincentives for the uptake of education and skill and augments their disadvantages in the labor market and reinforces the gender division of labor (Kingdon, 1998). The demographic factors, mainly fertility rates and family structure and composition, play crucial role in determining the status of women as unpaid workers (Aguirre et al., 2012; Grimshaw and Rubery, 2015). However, access to the basic infrastructure, especially safe water, sanitation, energy for lighting and fuel, transport and childcare have strong influence on the time spent for unpaid work. Moreover, the failure of state to provide alternatives for care and domestic assistance increases the burden of unpaid work, which leads to restraining women's choices for paid work, as it is expected that they have to provide this unpaid work (Neff et al., 2012; Das et al., 2015). Further, the endorsed roles in unpaid work constrain their choice of paid works, such as self-employment, home-based or part-time; casual, irregular, seasonal, and in the informal sector because these types of work provide poor remuneration without any kind of social security (Budlender, 2004; Maloney, 2004; Razavi, 2007; Kabeer, 2012). Furthermore, the low opportunity cost for unpaid work is reflected in the market, and paid domestic workers have experiences low status, low wages without any social security (Fig. 1).

In Indian context, the women's movement is centuries older than the modern feminism debate of gender equality (Pande, 2018). However, it has initiated with the religious equality shifted in the period of 1970s with the ideas of women scholars (GoI, 1974; Bhatt, 1988) those started questioning the development from gender perspectives, intersectionality and power inequality.

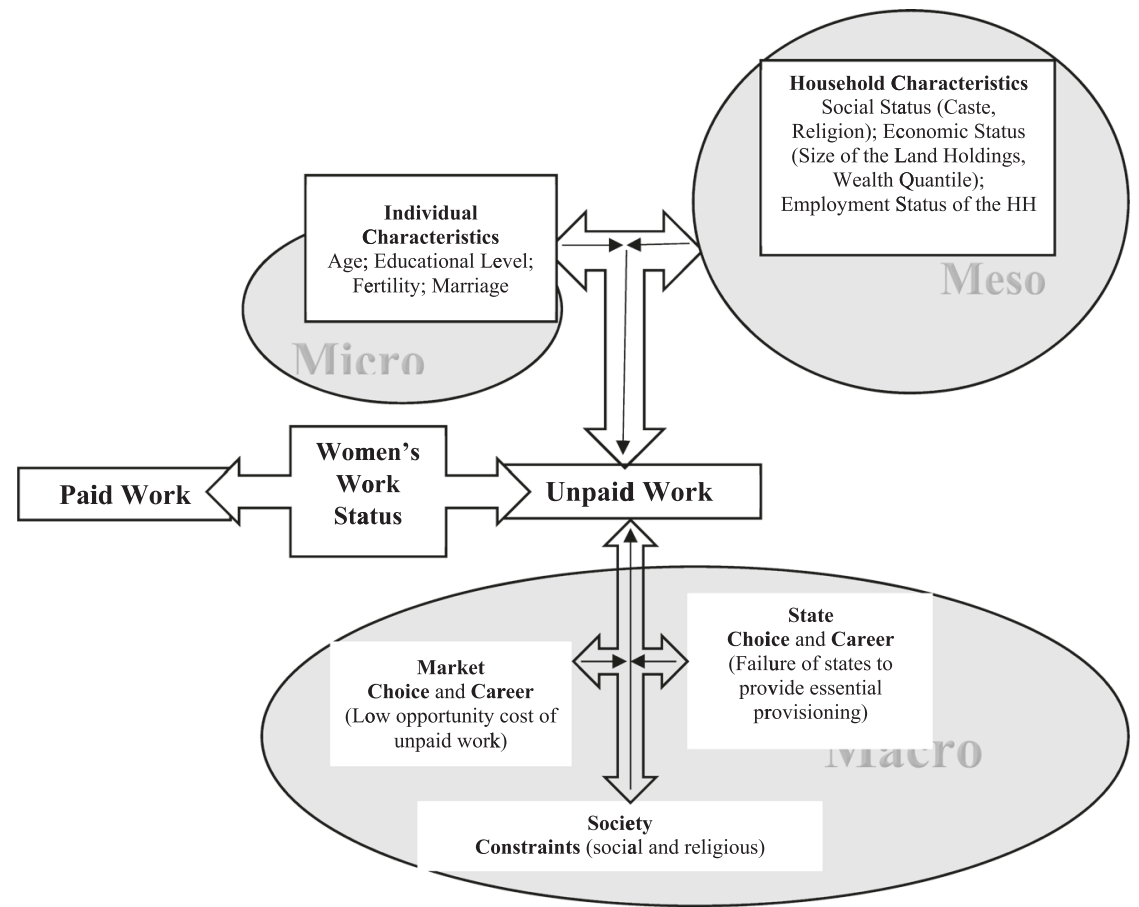

Fig. 1 Conceptual framework on women in domestic work-constraints, choices, and career: interconnection among macro, meso, and micro determinants. 
Although, gender equality has not fully achieved either at the religious or socio-economic sphere but the significance of their struggle cannot be neglected in the contemporary labor market (Esquivel et al., 2008; Antonopoulos and Hirway, 2010; IMF, 2013). It has been observed that the sexual division of labor pushes women to their domestic duties and undervalued household work. Therefore, categorically women are laid into margins of the society through the limitization of their role within the household (Jain, 1996; Sengupta, 2019). The social margins always haunted women in the economic and political sphere. Hence, in Indian social system, there are lack of agencies for women to access the labor market. Consequently, Omvedt (1987) discussed the prohibition of women in politics also leads to exclusion from productive work and property rights in society. The women representation in parliament is very much limited and the chances of the women contestants depends on the circumstantial win of the political organization (Jain, 2006; Allendorf, 2012). Thus, there is a systematic exclusion of women from the parliament has restricted their political agency to bring any protective labor legislation for unpaid workers.

Further, societal norms play a crucial role in women's work status and reduce participation in paid work (Elson, 1999; Das, 2006), which is further interceded through religion and caste (Eswaran et al., 2013). Therefore, women as the unpaid domestic workers become an indispensable reference point in the above said discussion as per the concept of intersectionality, which is used to describe the way in which caste, class, religion, social stigmas, and patriarchal norms generate discrimination, inequalities, and disempowerment. On the one hand, Indian households often require women to prioritize domestic work and they are also explicitly constrained by marriage, religion, caste, and economic class. However, on the other hand, they face legal, normative, and economic constraints to get paid work. The predominance of gender-biased views regarding women's roles in the household, economy, society, and political landscape of the country are the major impediments in changing the working status of women.

Furthermore, the state provides public provisioning (i.e., the level and quality of basic infrastructure especially water, sanitation, energy for lighting and fuel, transport, and childcare); however, it is very poor in quality and has strong influence on the time spent for unpaid work (Razavi, 2007; Budlender, 2010).
Here, the existing discourse on unpaid work reveals that though attention has been given to understand, conceptualize, measure, and evaluate its link with various aspects of women's lives including employment, more action is required in the form of policy framework to expand women's opportunities, choices, and freedoms, and to interconnect the dimensions of unpaid work that need to be Recognize, Reduce, and Redistribute (Three ' $R$ ' approach) in the economy. Therefore, the aim of the study is to assess the quantum of unpaid domestic work as well as to ascertain the multiple factors (i.e., educational status, economic status, type of domestic works, and caste) accountable for the growth of unpaid workers and to further understand the dynamics, labor market performance and institutional settings, structural characteristics and their interactions in the country.

\section{Concepts, database, and methodology}

Defining unpaid work. Unpaid work can be distinguished into a range of activities (Kabeer, 2008; Antonopoulos, 2009). Unpaid services provided for the maintenance and care of households are considered as unpaid domestic work. Unpaid household work has three components: (i) household maintenance including cooking, cleaning, and shopping; (ii) care of persons living in the house, such as looking after children, the elderly, sick, disabled, or simply other adults requiring care; and (iii) voluntary services or services rendered free to other households or the community. Despite its critical role in the sustenance of society, unpaid household work is considered Non-System of National Accounts (SNA) or Extended SNA (ESNA) work (SNA, 1993). Unpaid household work performed mainly by unpaid workers, overwhelmingly women, are thus rendered invisible in the official statistical systems; and, consequently out of the ambit, until the recent change of the national and international development policy (Antonopoulos and Hirway, 2010; Hirway, 2015).

The Indian scenario is somewhat different. The Indian Central Statistical Organization (CSO) does not include the processing of primary goods and collection of free goods in the computation of India's GDP, which means that workers engaged in these activities, mostly women, are excluded from the estimated workforce of the National Sample Survey Organization (NSSO) and the Population Census. The NSSO placed them under Codes 92 and 93, i.e., engaged in domestic duties and allied activities (Table 1) (NSSO, 1997, 2000, 2007, 2014). Being clubbed with

\section{Table 1 Measuring employment and unemployment status of household members by NSSO 50th round (1993-94) to 68th round (2011-12) rounds of NSSO.}

\section{Usual principal activity particulars of household members}

Socio-Economic Survey Schedule 10: employment and unemployment

Paid work

worked in household enterprise (self-employed): own account worker-11, employer-12,

worked as regular salaried/wage employee-31,

worked as casual wage labor: in public works -41 , in other types of work -51 ;

Unpaid home-based work

worked as helper in household. enterprise (unpaid family worker)-21;

Unpaid domestic work

attended domestic duties only-92,

attended domestic duties and was also engaged in free collection of goods (vegetables, roots, firewood, cattle feed, etc.), sewing, tailoring, weaving, etc. for household use-93,

Unemployed

did not work but was seeking and/or available for work-81,

Others (out of labor force)

attended educational institution-91,

rentiers, pensioners, remittance recipients, etc. -94 ,

not able to work due to disability-95,

others (including begging, prostitution, etc.)-97.

Source: National Sample Survey Office (NSSO) 
unpaid household workers, these SNA women workers are denied official recognition as workers, and hence, they have also remained invisible and excluded from Indian development policy. In recognition of the Indian situation, the report of the subcommittee about a system of Indian National Accounts (Government of India, 2015) includes unpaid SNA as well as unpaid household workers in its ambit, thereby treating both as part of the continuum of women's work. In case of necessity, the unpaid household discourse is extended to include unpaid SNA work/workers.

Data source. To accomplish the objectives, the data from various sources both at the micro and macro levels were utilized in this study. The National Sample Survey Office (NSSO) conducts a nationwide survey on the key indicators of the labor market, i.e., labor force and workforce participation rate according to the age group, level of schooling, gender perspective, unemployment rate, wages of employees, the extent of domestic duty, etc., in India. This study has considered the data on domestic duties of the 50th round (July 1993-June 1993), 55th round (July 1999-June 2000), 61st round (July 2004-June 2005), and 68th round (July 2011-June 2012) using a schedule of inquiry (Schedule 10) from all-India household survey on the subject of employment and unemployment $(\mathrm{EU})$ in India. The employment and unemployment (EUS) data were collected on the basis of person's activity, which included workers seeking/available for work as well as those who are out from the labor force; and further a set of questions was put to all the individual of the households engaged in the domestic duties. Moreover, this study considered only the information of domestic duties collected under the aspects related to "carrying on domestic duties only, (code-92)" and "carrying domestic duties along with being involved in the free collection of goods (roots, cattle feed, vegetables, firewood, etc.), weaving, sewing, tailoring, etc. for household purpose (code-93)". The participation in domestic duties were classified in term of their willingness to accept work in household, nature of duties, and kind of domestic responsibilities (Table 1). However, the followup questions asked in the NSSO $(1997,2000,2007,2014)$ Survey (under status code 92 or 93) focused on the various unpaid activities, wherein mostly women are engaged (Maintenance of garden, orchards, etc.; Work in HH. poultry, dairy, etc.; Free collection of fruits and vegetables, etc.; Free collection of fire wood, etc.; Preparing cow dung cakes; Sewing, Tailoring, etc.; Free tutoring of own/others' children; Bringing water from outside HH. Premises); further women also performed the domestic duties-outside the home (see Supplementary Table S1).

Statistical analysis. To estimate the magnitude of an unpaid domestic worker in India, we considered women age to be 15+ years at the aggregate level and at the state level. Thus, the following method was employed in this study:

Paid worker. 'Paid work' covers full-time and part-time employment such as who are self-employed, employer, regular salaried, and casual wage labor/other and getting remuneration for their work. Therefore,

$$
\text { Paid women worker }=\frac{\text { No. of women employed }(\text { paid })}{\text { Total women population }} \times 100
$$

Unpaid home-based worker (UHBW). The unpaid home-based workers refers to those who worked as a helper in the household (hh) enterprise and get no remuneration for their work

$$
\mathrm{UHBW}=\frac{\text { No. of women in hh enterprise }(\text { unpaid })}{\text { Total women population }} \times 100
$$

Unpaid domestic worker. The unpaid domestic workers are mainly women who attended domestic duties only and are engaged in household use work without remunerations

Women unpaid domestic worker

$$
=\frac{\text { No. of women in domestic duties }}{\text { Total women population }} \times 100
$$

In order to explore the dynamics involved in the paid and unpaid work; the socio-economic and demographic characteristics (like household consumption expenditure on monthly basis in quintiles, location in terms of urban/rural, education status, age, caste, religion, etc.) of the women performing the domestic duties were examined. To observe factors influencing women unpaid activities, the study applied the logistic regression. The logistic regression is normally used to estimate the probability of being unpaid domestic workers (Cerrutti, 2000). The benefit of logistic regression is that it needs no assumption for the distribution of the independent variables.

In this study, the independent variables comprised both the numerical and nominal measures, and the outcome variables were binary or dichotomous. The distribution of the predictor variables was checked and interpreted with the odds ratios.

The binary response variable considered as

$$
\text { Women work }=\left\{\begin{array}{l}
1=\text { if domestic duties } \\
0=\text { if paidwork }
\end{array}\right.
$$

and the set of explanatory variables for each individual was related to a set of categorical predictors (age, location in terms of urban/rural, education status, caste, economic status, religion, etc.). Further, the logistic function was depicted as

$$
\operatorname{logit}\left(\pi_{i j}\right)=\log \left[\pi_{i} /\left(1-\pi_{i}\right)\right]=\beta_{0}+\beta(X)+\varepsilon
$$

The probability of women in unpaid activities has been represented as $\pi_{i}$. The parameter $\beta_{0}$ estimated the log odds of women unpaid activities for the reference group, and the parameter $\beta$ estimated with maximum likelihood the differential log odds of unpaid women activities, which is associated with the predictor $X$, as compared to the reference group, and odds ratios (OR) with 95\% confidence interval (CI) has been considered.

\section{The magnitude of women unpaid domestic activity in India}

Despite the debate on gender inequality in SDG, women hold the principal position of the caregiver and carry out domestic work in the household. Their care and homemaking works are often ignored, undervalued, and recognized as unskilled work. Domestic 'unpaid' work involves performing routine household odd jobs such as cooking, cleaning, fetching food, collecting water, and firewood among others. The share of unpaid domestic work among women in India is high and gradually increasing; it also includes caring for the household members. Furthermore, women participation in paid work has declined by 11.1 percent, whereas, the magnitude of unpaid domestic work has increased by 12.2 percent from 1992-93 to 2011-12 in India (Fig. 2). Though family members make different contributions to ensure smooth functioning of the household, most of the domestic work is being carried out by women. Moreover, the results indicated that 60.9 percent of women population is engaged in unpaid domestic work in 2011-12 compared to 48.8 percent in 1993-94, 


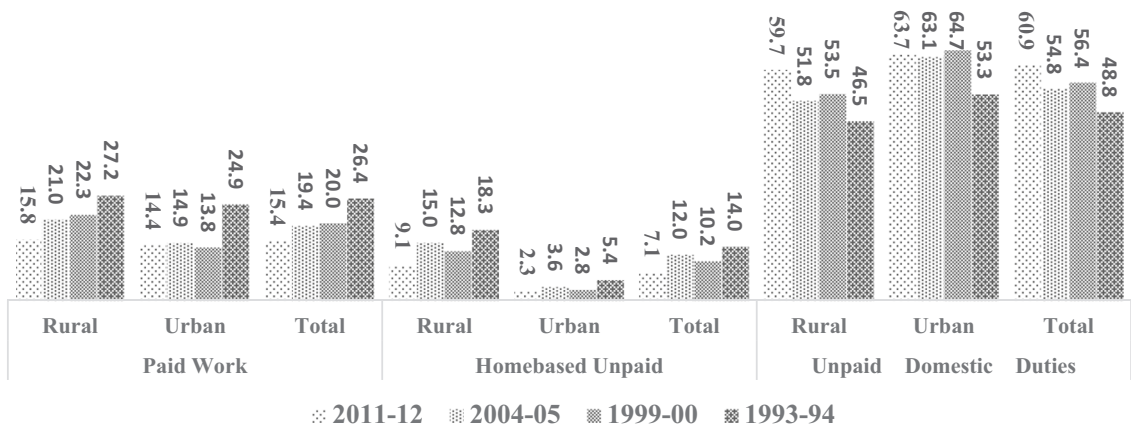

Fig. 2 Percentage distribution of women engaged in paid, homebased, and unpaid activities.

and the significant increment is evident among both the rural and urban women engaged in unpaid domestic work. Nearly, 63.7 percent of urban women are engaged in unpaid domestic work in 2011-12 compared to 53.3 percent in 1993-94, whereas, 59.7 percent of rural women are engaged in unpaid domestic work in 2011-12 compared to 46.5 percent in 1993-94 (see Supplementary Table S2).

It has been observed that the participation of women in unpaid domestic work is quite high in the urban areas compared to the rural areas and the burden of domestic duties is increasing with the passage of time in both the sectors. The reason is probably the limited and poorly remunerated employment opportunities for women, which have reduced the opportunity cost of unpaid work mostly in the urban areas. The low participation of women in unpaid domestic work in rural areas may be because most of the women in the rural area are engaged in agriculture, which is generally informal. It is an alarming indicator of the 'jobless formal sector', which is a matter of serious concern for 'decent work condition' and has serious consequences on poverty reduction, women empowerment, decent education for the girl child, etc. However, there is a huge gender gap in the unpaid domestic work in India may be because of social norms (gender stereotype work), demographic factors like fertility rates, family structure and composition, access to basic infrastructure/services (collecting water, and firewood), etc. Therefore, for a deeper understanding of the dynamics of labor market, there is need for further analysis of different dimensions like age distribution, educational attainment, marital status, wealth distribution, etc., of women engaged in unpaid domestic work in India.

Taxonomy of women unpaid domestic workers in India: socioeconomic and demographic dimensions. Though the female populace constitutes half of the total population, women are still invisible in their contribution toward macroeconomics in terms of their labor market representation and their share in economic productivity. It indicates that women contribute less than their potential to the economy (Hirway, 2015; Addati et al., 2018) because a significant segment of women is engaged in unpaid work. Thus, this study has explored the burden of unpaid domestic activities on women as per their socio-economic and demographic characteristic (Table 2). Age could be considered as indicators of women's experiences over the years and their social contracts in the form of marriage, motherhood, etc., as well as it gives a notion of the women's work participation opportunities in the economic activities. Therefore, the incidence of unpaid domestic activities is much higher in the 25-34 age group, which is also evident through the results. Across the Indian households, it is the social custom that women must take care of their families; hence, most of the women after marriage adopt home care as the permanent unpaid job. Further, the patriarchal tendency of naming a woman as a housewife is very common among the Indian households (Dube, 1998), which restricts her decision about entering the economic activities in the labor market, thereby legitimizing unpaid domestic duty as the destiny (Chakravarti, 1993).

Therefore, education plays a significant role in bringing changes in these gendered norms of a society that have significant impact on women's work status (Marphatia and Moussié, 2013). Hence, the results of this study revealed that 60.6 percent of illiterate women are engaged in unpaid domestic work in 2011-12. In practice, studies show that girls performing high proportion of domestic work have low level of schooling (Dong and An, 2015). However, it is interesting to note that the participation rate of women in unpaid domestic work between intermediary and graduate level of education has increased significantly. Nearly 57.8 percent of women have completed their intermediary level of education and above, but are engaged in unpaid domestic work. In urban areas, 62.1 and 56.8 percent of women having intermediary and graduate level of education are engaged in unpaid domestic work, whereas, in rural areas the percentage is 54.8 and 50.9, respectively. The low opportunity cost of unpaid work in a market economy, mostly in urban areas, restricts the choice of women to go for paid work. However, it has been observed that women having technical education are less employed in unpaid work. It seems that vocational education plays a potentially empowering role in the process of moving from an unpaid status to paid working status. Furthermore, research also shows the influence of castes and religious groups on the work status of girls and women. In specific religious communities like Hindus and Muslims, the unjust traditions, norms, and practices create a distinct division of labor between women and men, and further disseminate the work status of women as an unpaid domestic worker. However, it has been observed that a woman's ability to participate in the labor force has been affected by their affiliation to certain social groups. Women from marginalized communities, i.e., schedule caste (SC) and scheduled tribe (ST) are supposed to have lower levels of income as compared to other groups (Singh and Pattanaik, 2020), which creates a negative effect on women's participation in the labor market compared to other backward class (OBC)/others. In STs and SCs communities, women are not discriminated on the basis of the division of labor (Neetha, 2010) because along with domestic works, women also engage in small-scale subsistence farming and sometimes as paid agricultural labor.

The associations between unpaid work and living standards have been largely ignored (Hirway, 2015). Income distribution, size of land holding, and employment status could be significant parameters to understand women's work status in their household. During the study period, it has been observed that women belonging to the poorest and highest wealth quantiles show more engagement in the unpaid activities than women belonging to the 
Table 2 Distribution of women engaged in domestic work by socio-economic characteristics.

\begin{tabular}{|c|c|c|c|c|c|c|c|c|c|c|c|c|}
\hline \multirow[t]{2}{*}{ Background characteristics } & \multicolumn{3}{|c|}{ 2011-12 } & \multicolumn{3}{|c|}{ 2004-05 } & \multicolumn{3}{|c|}{ 1999-00 } & \multicolumn{3}{|c|}{ 1993-94 } \\
\hline & Rural & Urban & Total & Rural & Urban & Total & Rural & Urban & Total & Rural & Urban & Total \\
\hline \multicolumn{13}{|l|}{ Age } \\
\hline $15-24$ & 49.5 & 39.7 & 46.6 & 52.4 & 46.3 & 50.7 & 54.3 & 49.4 & 53.0 & 45.1 & 41.7 & 43.9 \\
\hline $25-34$ & 72.0 & 75.3 & 73.0 & 57.9 & 74.9 & 62.4 & 58.5 & 78.8 & 63.9 & 50.2 & 62.4 & 54.2 \\
\hline $35-49$ & 63.5 & 75.6 & 67.1 & 50.2 & 72.4 & 56.3 & 52.9 & 74.6 & 58.8 & 45.7 & 58.2 & 49.9 \\
\hline $50-59$ & 62.9 & 75.4 & 66.6 & 53.0 & 72.2 & 58.0 & 55.6 & 69.3 & 58.9 & 47.9 & 58.1 & 51.1 \\
\hline $60+$ & 46.2 & 52.0 & 47.9 & 39.7 & 46.7 & 41.5 & 39.7 & 43.3 & 40.6 & 40.6 & 43.9 & 41.7 \\
\hline \multicolumn{13}{|l|}{ Education } \\
\hline Illiterate & 59.7 & 65.1 & 60.6 & 49.2 & 61.3 & 51.0 & 50.4 & 62.9 & 52.2 & 44.1 & 54.4 & 46.2 \\
\hline Bel Primary & 68.6 & 69.7 & 68.9 & 58.7 & 68.9 & 61.1 & 61.6 & 71.9 & 64.3 & 52.9 & 62.2 & 56.1 \\
\hline Primary & 66.1 & 73.7 & 68.1 & 60.3 & 72.3 & 63.7 & 62.1 & 76.5 & 66.5 & 54.4 & 64.0 & 58.1 \\
\hline Up to Inter & 54.8 & 62.1 & 57.8 & 51.8 & 62.3 & 56.2 & 57.4 & 63.2 & 60.0 & 49.0 & 51.3 & 50.3 \\
\hline Graduate+ & 50.9 & 56.8 & 55.2 & 45.8 & 56.6 & 54.1 & 45.0 & 57.4 & 54.9 & 31.6 & 35.8 & 35.1 \\
\hline \multicolumn{13}{|l|}{ Tech. education ${ }^{a}$} \\
\hline No Tech Edu & 59.9 & 64.8 & 61.3 & 51.9 & 64.2 & 55.1 & 53.5 & 65.5 & 56.6 & 46.6 & 54.5 & 49.2 \\
\hline Graduate in Tech & 18.1 & 18.6 & 18.6 & 25.9 & 22.3 & 23.0 & 37.8 & 37.0 & 37.3 & 22.5 & 19.1 & 20.1 \\
\hline Tech Dip Bel Grad & 35.2 & 34.1 & 34.5 & 29.4 & 32.5 & 31.1 & & & & & & \\
\hline Tech Dip Grad/ab & 22.3 & 31.0 & 29.2 & 27.6 & 27.9 & 27.8 & & & & & & \\
\hline \multicolumn{13}{|l|}{ Religion } \\
\hline Hindu & 58.3 & 62.6 & 59.5 & 49.4 & 62.2 & 52.6 & 51.8 & 64.1 & 54.9 & 45.6 & 53.0 & 47.9 \\
\hline Muslim & 70.7 & 71.7 & 71.0 & 70.2 & 70.9 & 70.5 & 70.0 & 72.0 & 70.7 & 66.4 & 64.4 & 65.4 \\
\hline Christianity & 49.6 & 46.2 & 48.4 & 42.9 & 46.4 & 44.0 & 43.7 & 49.5 & 45.5 & 28.3 & 33.8 & 30.4 \\
\hline Others ${ }^{b}$ & 65.8 & 66.7 & 66.1 & 58.9 & 63.1 & 60.1 & 64.2 & 65.9 & 64.7 & 55.1 & 61.3 & 56.8 \\
\hline \multicolumn{13}{|l|}{ Caste } \\
\hline Scheduled tribes & 45.7 & 55.9 & 46.9 & 32.7 & 49.8 & 34.4 & 33.1 & 55.5 & 35.7 & 30.8 & 37.1 & 32.1 \\
\hline Scheduled castes & 59.6 & 60.9 & 59.9 & 51.7 & 61.1 & 53.6 & 51.5 & 62.5 & 53.5 & 45.7 & 49.7 & 46.7 \\
\hline $\mathrm{OBC}$ & 60.3 & 64.2 & 61.4 & 50.9 & 61.7 & 53.4 & 53.3 & 64.1 & 55.8 & 50.0 & 55.4 & 52.0 \\
\hline Others ${ }^{c}$ & 64.9 & 64.7 & 64.8 & 60.3 & 65.5 & 62.4 & 62.9 & 66.6 & 64.3 & & & \\
\hline \multicolumn{13}{|l|}{ Wealth quintile } \\
\hline Poorest & 62.8 & 65.5 & 63.1 & 49.2 & 61.1 & 50.3 & 50.4 & 54.7 & 51.2 & 45.4 & 55.5 & 47.3 \\
\hline Poor & 59.8 & 65.0 & 60.7 & 52.0 & 62.6 & 53.7 & 52.7 & 58.7 & 53.8 & 46.7 & 54.9 & 48.8 \\
\hline Middle & 57.1 & 65.5 & 59.4 & 53.5 & 63.4 & 55.9 & 57.9 & 68.3 & 60.6 & 47.6 & 55.3 & 50.0 \\
\hline Rich & 56.5 & 64.8 & 60.1 & 53.0 & 65.8 & 57.6 & 58.3 & 72.9 & 64.4 & 47.5 & 54.8 & 50.4 \\
\hline Richest & 57.6 & 61.0 & 60.0 & 55.4 & 61.9 & 59.6 & 50.4 & 66.1 & 60.0 & 45.1 & 49.5 & 47.4 \\
\hline \multicolumn{13}{|l|}{ Land size (hectares) } \\
\hline$<0.004$ & 57.4 & 64.3 & 61.0 & 45.8 & 63.7 & 55.0 & 52.2 & 65.1 & 58.4 & 44.2 & 54.9 & 50.2 \\
\hline $0.005-0.400$ & 62.7 & 64.4 & 63.2 & 55.7 & 63.7 & 58.0 & 58.8 & 61.9 & 59.1 & 47.7 & 49.8 & 48.2 \\
\hline $0.410-1.000$ & 58.9 & 60.0 & 58.9 & 51.5 & 60.4 & 52.0 & 53.9 & 61.7 & 54.3 & 44.6 & 47.9 & 44.9 \\
\hline $1.01-2.00$ & 54.9 & 65.2 & 55.6 & 49.2 & 61.7 & 49.8 & 52.4 & 65.1 & 53.1 & 46.7 & 50.0 & 47.0 \\
\hline $2.01-4.00$ & 55.8 & 64.7 & 56.6 & 47.2 & 59.7 & 48.0 & 51.4 & 61.6 & 51.9 & 49.7 & 55.7 & 50.2 \\
\hline$>4$ & 59.7 & 64.4 & 60.3 & 48.1 & 58.9 & 49.0 & 52.7 & 70.1 & 53.9 & 51.6 & 55.8 & 51.9 \\
\hline \multicolumn{13}{|l|}{ Household type } \\
\hline Self-employed & 60.8 & 66.1 & 62.1 & 48.6 & 65.8 & 53.4 & 48.2 & 67.3 & 52.8 & 41.0 & 57.5 & 47.0 \\
\hline Regular wage & 60.0 & 62.5 & 61.6 & 53.4 & 62.1 & 58.5 & 57.7 & 64.7 & 62.4 & 42.5 & 52.5 & 50.0 \\
\hline Casual labor & 57.2 & 63.9 & 58.1 & 52.3 & 58.6 & 52.8 & 56.5 & 59.5 & 56.8 & 49.1 & 43.4 & 48.5 \\
\hline Other & 64.5 & 55.9 & 61.0 & 60.7 & 59.0 & 60.4 & 62.9 & 62.5 & 62.8 & 54.7 & 52.9 & 54.3 \\
\hline \multicolumn{13}{|l|}{ State region } \\
\hline Central & 63.7 & 68.5 & 64.8 & 57.1 & 69.3 & 59.7 & 59.2 & 69.1 & 61.3 & 53.8 & 61.0 & 55.9 \\
\hline Eastern & 74.6 & 68.3 & 73.4 & 68.5 & 67.8 & 68.4 & 67.8 & 69.1 & 68.0 & 61.7 & 60.2 & 61.3 \\
\hline North-eastern & 65.1 & 58.7 & 64.2 & 62.0 & 58.3 & 61.5 & 63.1 & 57.8 & 62.3 & 41.7 & 40.7 & 41.4 \\
\hline Northern & 59.3 & 66.7 & 61.8 & 57.7 & 65.7 & 60.3 & 63.8 & 69.1 & 65.5 & 57.1 & 62.7 & 58.8 \\
\hline Southern & 42.9 & 58.0 & 48.4 & 33.0 & 54.7 & 39.6 & 37.2 & 58.9 & 43.8 & 31.1 & 46.8 & 37.3 \\
\hline Western & 50.3 & 62.6 & 55.7 & 35.3 & 63.5 & 46.1 & 35.5 & 63.7 & 46.0 & 33.0 & 53.2 & 41.9 \\
\hline Total & 59.7 & 63.7 & 60.9 & 51.8 & 63.1 & 54.8 & 53.5 & 64.7 & 56.4 & 46.5 & 53.3 & 48.8 \\
\hline \multicolumn{13}{|c|}{$\begin{array}{l}\text { HH household. } \\
\text { a1993 and } 2000, \text { Technical Education is in two-part technical and non-technical only. } \\
\text { bOthers includes Sikhism, Jainism, Buddhism, and Zoroastrianism. } \\
\text { cOthers represents non-SC/ST/OBC groups and for } 1993 \text { OBC+Others combined. } \\
\text { Source: Calculations of data done by the authors based on 50th round (1993-94) to }\end{array}$} \\
\hline
\end{tabular}

middle wealth quantiles household. The effect of rising household income becomes a pull factor behind changing the work status of women in the household (Kambhampati, 2009). A high percentage of women are engaged in unpaid domestic work in the households having small and marginal land holdings $(<0.004$ and $0.005-0.0400 \mathrm{ha}$ ).

Furthermore, the structural transformation and automation of agriculture have led to the mechanization of work, which has pushed women to exit from farm activities, especially from the middle and higher large size of landholding and to engage in unpaid activities (Schultz, 1990; Mehrotra et al., 2012). Thus, it shows that the unpaid domestic activities are more prevalent in the two extreme strata of the economy (the poorest and highest wealth quantiles, smallest and largest size of the land holdings of the household). Further, according to the household employment status, the percentage of women engaged in unpaid activities are higher in the self-employed household (62.1 percent) and household of casual laborers (58.1 percent), respectively, in 2011-12.

Furthermore, the most important indicator of regional imbalance in unpaid domestic duties highlights the opportunities available for women human resources in specific regions. The eastern region (73.4 percent) has higher women domestic workers for household work followed by the central region (64.8 percent) in 2011-12. The perusal of Table S4 in the supplementary reveals a dramatic increase in the domestic duties from 48.8 percent to 60.9 percent between 1993-94 and 2011-12 for India as a whole; a similar increase has been witnessed in each of the states. Among 
the eastern states, Bihar has shown the highest increase in the unpaid domestic duties from 2004-05 (76.4 percent) to 2011-12 (81.5 percent) followed by the northern states Punjab and Haryana. The inter-state variation in the burden of unpaid work is glaring in the southern states compared to northern states. Broadly, in the intra-state context, the socio-cultural norms are likely to determine women economic status, which indicates that the survival of the household is unimaginable without the contribution of women as unpaid domestic workers. Therefore, it can be inferred that increase in the education level of women, increase in family income, large size of land holdings, and regular employment status of the household can be considered as positive parameters for changing women's work status because with a better standard of living and higher income level, the household can afford care services, which in turn will give choices to the women to redistribute their time both at home as well as at the workplace.

Whys and wherefores: women in domestic work-constraints, choices, and career. A number of inquisitions have been put to the household member engaged in unpaid domestic work for understanding the prospects of spending Most of their time on domestic duties (MTDD). The estimates of this study revealed that 91.9 percent of women are required to spend most of their time on unpaid domestic activities in 2011-12 compared to 86.9 percent in 1993-94 (Table 3), which highlights that the proportion of women engaged in domestic duties has increased. It has been observed that in 2011-12, 61.3 percent of women reported that they have to carry domestic work because there is 'no other member to carry out the domestic duties', 15.3 percent reported that they have to carry the domestic work 'for social and/or religious constraints', 8.8 percent reported that they 'cannot afford hired help', and 14.6 percent gave some 'other reasons'. Hence, the theoretical debate surrounding the triple " $R$ " approach of unpaid work (Elson, 2017) - neither of redistribution, recognition, reduction on their own are means of achieving a high status for women in the economy is possible in practice-because women's current low status in the Indian economy is linked to their disproportionate share of unpaid care work and lack of access to paid employment. Within the household, the 'redistribution' of unpaid work requires change in the prevailing patriarchal norms and customs (Kabeer, 1994; Fraser, 2001; Fletcher et al., 2017). Further, in Indian society, the 'recognition' of women's roles in nourishing families is often denied and undervalued (Palriwala and Neetha, 2011).

Moreover, for the 'reduction' in unpaid work to diminish drudgery as well as stress of unpaid workers, the state has also failed to make accessible basic infrastructural support (e.g., providing water supply, fuel, transport, caregiving institutions, etc.) to the household. Indian women are engaged in unpaid activities not by choice; rather they are constrained because institutions (both market and state) have failed to create alternatives. While examining the proportions of women engaged in MTDD across age group, it has been observed that the proportion is higher among all the age groups, but for the age group 25-34, it has increased significantly during the study period (1993-94 to 2011-12), i.e., from 88.8 percent to 94.1 percent. It is the time of life transition for women belonging to the age group 25-34, specifically because it is their age of marriage, childbearing, and careers mobility, which shapes the distribution of unpaid domestic work in households (McMullin, 2005). Further, the proportion of women engaged in MTDD is significantly high irrespective of their educational status and wealth distribution of the household (see Supplementary Table S3).

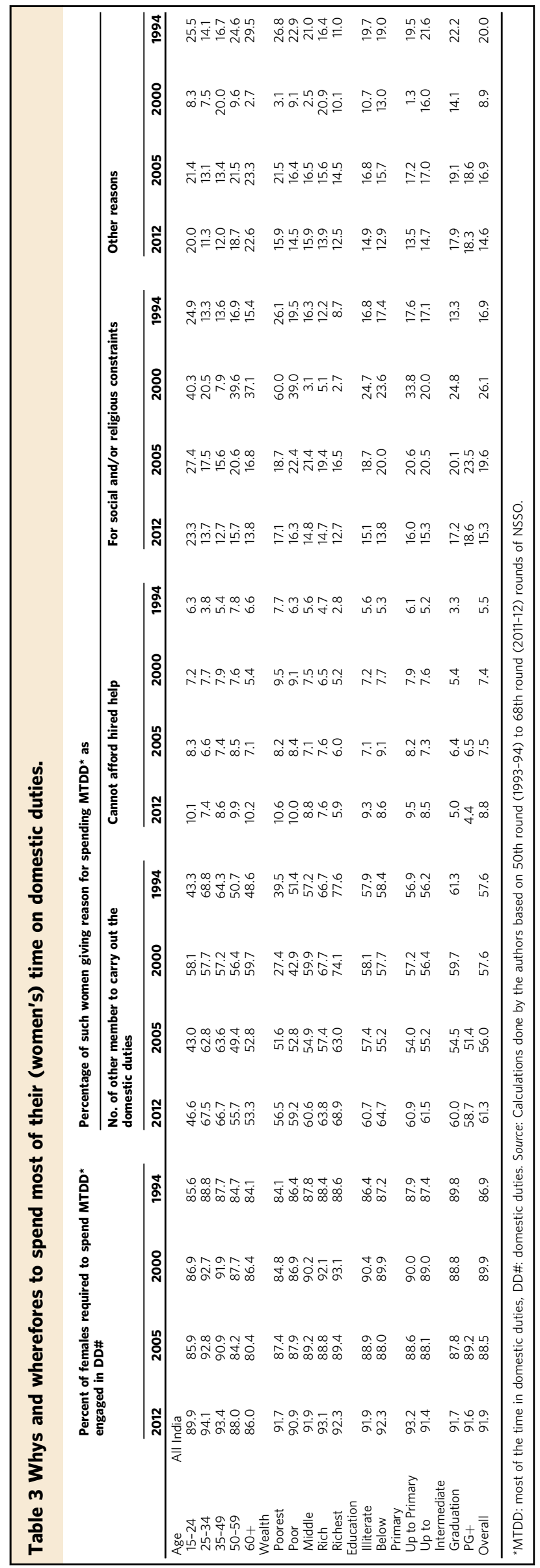


Table 4 Various other activities performed by women along with domestic duties.

\begin{tabular}{|c|c|c|c|c|c|c|c|c|}
\hline \multirow[t]{2}{*}{ Activities } & \multicolumn{2}{|c|}{ 2011-12 } & \multicolumn{2}{|c|}{ 2004-05 } & \multicolumn{2}{|c|}{ 1999-00 } & \multicolumn{2}{|c|}{ 1993-94 } \\
\hline & Rural & Urban & Rural & Urban & Rural & Urban & Rural & Urban \\
\hline Maintenance of garden, orchards, etc. & 23.5 & 7.8 & 15.8 & 3.2 & 13.8 & 3.4 & 17.3 & 5.2 \\
\hline Work in $\mathrm{HH}$, poultry, dairy, etc. & 21.6 & 2.4 & 33.2 & 3.9 & 32.1 & 4.4 & 41.3 & 9.0 \\
\hline Free collection of fruit, veg, etc. & 18.9 & 1.8 & 16.3 & 1.2 & 14.9 & 1.2 & 20.9 & 2.4 \\
\hline Free collection of fire wood, etc. & 43.5 & 5.3 & 39.7 & 5.7 & 39.0 & 5.4 & 43.6 & 8.1 \\
\hline Preparing cow dung cakes & 41.1 & 4.6 & 46.5 & 5.7 & 48.2 & 5.8 & 56.6 & 11.0 \\
\hline Sewing, tailoring, etc. & 27.6 & 23.6 & 28.4 & 26.0 & 26.9 & 27.1 & 23.7 & 26.8 \\
\hline Free tutoring of own/others' children & 6.9 & 12.1 & 7.0 & 12.6 & 5.8 & 13.1 & 4.3 & 12.5 \\
\hline Bringing water from outside $\mathrm{HH}$. Premises & 30.5 & 9.6 & 44.5 & 19.3 & 49.9 & 22.7 & 59.7 & 30.2 \\
\hline
\end{tabular}

Various other activities performed by women along with unpaid domestic duties. The focus of analysis in this section is to examine the extra work (outside home) along with the domestic duties and distribution patterns of women engaged in MTDD. The activities listed in Table 4 fall within the 'Unpaid Work' according to Indian System of National Accounts (ISNA), and if women perform these activities, they are not considered as worker. Though the results revealed that the participation of women in all the specified domestic unpaid activities has declined over the study period, huge variation has been observed across the rural and urban sectors.

It has been reported that in 2011-12, 43.5 percent women are engaged in the collection of free firewood in rural areas compared to 5.3 percent in urban areas; 41.1 percent women are engaged in preparing cow dung cakes in rural areas compared to 5.3 percent in urban areas; and 30.5 percent women are engaged in bringing water from outside household premises in rural areas compared to 9.6 percent in urban areas.

This seems that the state institution has failed to provide basic infrastructure facilities (i.e., cooking fuel, drinking water) at the doorstep of the household. Furthermore, it has been reported that 27.6 percent women are engaged in sewing and tailoring activities in rural areas compared to 23.6 percent in urban areas and 23.5 percent women are engaged in the maintenance of kitchen and garden within household premises in rural areas compared to 7.8 percent in urban areas in 2011-12. Women devote substantial time to productive unpaid activities like cooking, cleaning, caring, gardening, etc. Likewise, 21.6 percent women are engaged in poultry and dairy work, and 21.6 percent women are engaged in the free collection of fruits and vegetables in rural areas in 2011-12. These unpaid activities represent implicit income because they increase the overall consumption of goods and services (Becker, 1965), but in India, these activities are done by women in the form of non-market services.

Most of the rural women come from small peasant family that owns less than an acre of land for cultivation or from a landless family who often depends on the feudal lords for work and wage. The rural women are generally illiterate and have not traveled more than 20 miles from her birthplace. Since her birth; she has been taught that she will get married and serve her husband. The rural women have multiple pre-define traditional work schedule, as she has to perform all the household responsibilities such as collecting firewood, washing, cultivating, and husbandry. In this section, we will discuss women's drudgery in their engagement in domestic duties. She has to wake up early and start washing dishes and cleaning the house while also taking care of her family and whims of her husband. She has to then rush to their field for work in the hot sun. In the afternoon, i.e., during lunchtime at the workplace, she does not take rest; rather she indulges in collecting some grass and firewood for the cooking at home in the evening.
After coming back from work in the evening, she has to cook for her family.

The SDG target 7.1 makes promises to ensure universal access to affordable, reliable, and modern energy services for every household by 2030. According to the Census (2011), there are 63 percent of rural households that use firewood, 23 percent use cow dung cakes, and 11 percent use liquefied petroleum gas (LPG) as primary cooking fuel. In rural households, women have to bear cooking responsibilities. For the poor households, women also have to bear the responsibility of procuring fuel for cooking, which means to cook she needs fuel; either from firewood or cowdug cakes. To collect the firewood, she has to walk several miles every day, and for cow dung, she must feed the cow for which she must collect suitable grasses regularly, which also needs her to walk several miles. These rural women spend about $4-5 \mathrm{~h}$ a day to collect fuel needed for cooking (Nagbrahmam and Sambrani, 1983). The irony is that she has to perform multiple tasks at a time such as while cooking, she has to breastfeed one child. Suppose she fails to perform any of the tasks or cannot perform them well, she is abused by her husband. Women have not been able to change their plight in the last thousands of years (Banerjee et al., 2018; Baquié and Urpelainen, 2017).

After the collection of fuel for cooking, she has to cook food for which she needs water, and to collect water she has to again walk several miles on foot. In some cases, she or her children have to fetch water from beyond the premises of the household, and it takes up to six trips a day to gather and transport water. Women carry buckets on their heads and walk daily around two/three miles on average for collecting water (Crow and McPike, 2009). It is also common for the rural girl child to help her mother in these domestic duties; hence, she has to drop her schooling. It is a great loss of productive hours for women who spend their time to fetch water, which in turn reduces their ability to contribute to their household income. The lack of water availability for sanitation in schools is also the reason behind most of the rural girl child not being able to go to school. The problem becomes more severe once a girl starts menstruation; it is very difficult and embarrassing for her to take care of herself in absence for water and toilet for sanitation. Further, animal husbandry in rural areas is extremely desirable to supplement household income. Therefore, women have to perform animal feeding, breeding, milking, caring of newborn calves, sick animals, etc., which contribute to the major burden of livestock management (Shiva, 1991). Apart from this, women also have to manage and arrange the supply of feed and fodder for the cattle (Patel et al., 2016). The poultry farming is also associated with husbandry, which is traditional and old age practice of the under privileged society, particularly in the hilly rural areas. The care of poultry birds and eggs are also the duty of women.

We observed a large degree of the feminization of all activities (cultivation, animal husbandry, collection of fodder, water, 
Table 5 Relative contributions of determinants on domestic duties of women in India.

\begin{tabular}{|c|c|c|c|c|c|c|c|c|}
\hline Background characteristics & \multicolumn{2}{|l|}{ 2011-12 } & \multicolumn{2}{|c|}{ 2004-05 } & \multicolumn{2}{|c|}{ 1999-00 } & \multicolumn{2}{|l|}{ 1993-94 } \\
\hline \multicolumn{9}{|l|}{ Sector } \\
\hline Urban & $1.37^{\star \star \star}$ & {$[1.32-1.43]$} & $1.79^{\star \star \star}$ & {$[1.73-1.86]$} & $2.19^{\star \star \star}$ & {$[2.11-2.28]$} & $1.86^{\star \star \star}$ & {$[1.80-1.92]$} \\
\hline \multicolumn{9}{|l|}{ Age } \\
\hline \multicolumn{9}{|l|}{$35-49^{\circledR}$} \\
\hline $50-59$ & $1.10^{\star \star \star}$ & {$[1.05-1.16]$} & $1.31^{\star \star \star}$ & {$[1.25-1.37]$} & $1.30^{\star \star \star}$ & {$[1.24-1.36]$} & $1.33^{\star \star \star}$ & {$[1.28-1.38]$} \\
\hline $60+$ & $1.76^{\star \star \star}$ & {$[1.65-1.89]$} & $2.34^{\star \star \star}$ & {$[2.20-2.48]$} & $2.28^{\star \star \star}$ & {$[2.14-2.42]$} & $1.92^{\star \star \star}$ & {$[1.83-2.02]$} \\
\hline \multicolumn{9}{|l|}{ Education } \\
\hline \multicolumn{9}{|l|}{ Illiterate } \\
\hline Bel Primary & $1.26^{\star \star \star}$ & {$[1.19-1.34]$} & $1.43^{\star \star \star}$ & {$[1.36-1.51]$} & $1.63^{\star \star \star}$ & {$[1.55-1.72]$} & $1.75^{\star \star \star}$ & {$[1.68-1.82]$} \\
\hline Primary & $1.29^{\star \star \star}$ & {$[1.22-1.37]$} & $1.68^{\star \star \star}$ & {$[1.60-1.76]$} & $2.10^{\star \star \star}$ & {$[2.00-2.21]$} & $2.20^{\star \star \star}$ & {$[2.11-2.29]$} \\
\hline \multicolumn{9}{|l|}{ Religion } \\
\hline \multicolumn{9}{|l|}{ Hindu ${ }^{\oplus}$} \\
\hline Muslim & $1.79^{\star \star \star}$ & {$[1.69-1.89]$} & $2.06^{\star \star \star}$ & {$[1.95-2.17]$} & $2.00^{\star \star \star}$ & {$[1.90-2.10]$} & $2.04^{\star \star \star}$ & {$[1.95-2.13]$} \\
\hline Christianity & $0.82^{\star \star \star}$ & {$[0.77-0.88]$} & $0.72^{\star \star \star}$ & {$[0.68-0.77]$} & $0.77^{\star \star \star}$ & {$[0.73-0.83]$} & $0.74^{\star \star \star}$ & {$[0.70-0.78]$} \\
\hline Others ${ }^{b}$ & $0.86^{\star \star \star}$ & [0.80-0.93] & $0.79^{\star \star \star}$ & [0.74-0.84] & $1.02^{\star \star \star}$ & [0.95-1.09] & $0.71^{\star \star \star}$ & {$[0.68-0.75]$} \\
\hline \multicolumn{9}{|l|}{ Caste } \\
\hline \multicolumn{9}{|l|}{ Scheduled Tribes ${ }^{\circledR}$} \\
\hline Scheduled Castes & $1.63^{\star \star \star}$ & {$[1.53-1.74]$} & $2.06^{\star \star \star}$ & {$[1.95-2.18]$} & $1.92^{\star \star \star}$ & {$[1.82-2.03]$} & $1.47^{\star \star \star}$ & {$[1.40-1.53]$} \\
\hline $\mathrm{OBC}$ & $2.00^{\star \star \star}$ & {$[1.89-2.12]$} & $2.55^{\star \star \star}$ & {$[2.43-2.68]$} & $2.77^{\star \star \star}$ & [2.64-2.91] & $2.12^{\star \star \star}$ & {$[2.03-2.20]$} \\
\hline Others ${ }^{\mathrm{C}}$ & $2.12^{\star \star \star}$ & {$[2.00-2.25]$} & $3.09^{\star \star \star}$ & {$[2.93-3.26]$} & $3.71^{\star \star \star}$ & [3.53-3.90] & & \\
\hline Wealth quintile & & & & & & & & \\
\hline Poorest $^{\circledR}$ & & & & & & & & \\
\hline $2.01-4.00$ & $1.80^{\star \star \star}$ & [1.64-1.98] & $1.83^{\star \star \star}$ & {$[1.69-1.97]$} & $2.09^{\star \star \star}$ & [1.94-2.26] & $2.21^{\star \star \star}$ & {$[2.10-2.33]$} \\
\hline$>4$ & $2.09^{\star \star \star}$ & {$[1.87-2.33]$} & $2.33^{\star \star \star}$ & {$[2.13-2.55]$} & $3.02^{\star \star \star}$ & {$[2.75-3.33]$} & $3.50^{\star \star \star}$ & [3.29-3.73] \\
\hline Household type & & & & & & & & \\
\hline Regular Wage ${ }^{\circledast}$ & & & & & & & & \\
\hline Self Employed & $1.62^{\star \star \star}$ & {$[1.55-1.69]$} & $1.12^{\star \star \star}$ & [1.08-1.17] & $0.82^{\star \star \star}$ & [0.79-0.85] & $0.96^{\star}$ & {$[0.93-1.00]$} \\
\hline Casual Labor & $0.77^{\star \star \star}$ & {$[0.73-0.81]$} & $1.62^{\star \star \star}$ & [1.54-1.69] & $1.51^{\star \star \star}$ & [1.44-1.58] & $1.71^{\star \star}$ & {$[1.64-1.77]$} \\
\hline Other & $4.23^{\star \star \star}$ & {$[3.75-4.78]$} & $1.73^{\star \star \star}$ & {$[1.64-1.83]$} & $1.83^{\star \star \star}$ & {$[1.72-1.94]$} & $1.73^{\star \star \star}$ & {$[1.64-1.81]$} \\
\hline State region & & & & & & & & \\
\hline Southern ${ }^{\circledast}$ & & & & & & & & \\
\hline Central & $2.81^{\star \star \star}$ & [2.66-2.97] & $3.41^{\star \star \star}$ & [3.26-3.57] & $2.85^{\star \star \star}$ & [2.73-2.98] & $3.44^{\star \star \star}$ & {$[3.32-3.57]$} \\
\hline Eastern & $3.96^{\star \star \star}$ & [3.73-4.20] & $5.34^{\star \star \star}$ & [5.09-5.61] & $3.78^{\star \star \star}$ & [3.62-3.96] & $4.24^{\star \star \star}$ & [4.08-4.40] \\
\hline North-Eastern & $1.76^{\star \star \star}$ & [1.66-1.88] & $2.46^{\star \star \star}$ & [2.33-2.60] & $1.99^{\star \star \star}$ & {$[1.89-2.10]$} & $1.78^{\star \star \star}$ & {$[1.71-1.85]$} \\
\hline Northern & $2.10^{\star \star \star}$ & {$[1.98-2.21]$} & $3.49^{\star \star \star}$ & [3.32-3.67] & $3.84^{\star \star \star}$ & {$[3.65-4.05]$} & $4.44^{\star \star \star}$ & {$[4.26-4.63]$} \\
\hline Western & $1.53^{\star \star \star}$ & {$[1.44-1.62]$} & $1.55^{\star \star \star}$ & [1.48-1.63] & $1.28^{\star \star \star}$ & [1.23-1.34] & $1.39^{\star \star \star}$ & {$[1.34-1.44]$} \\
\hline Const. & $0.12^{\star \star \star}$ & {$[0.10-0.14]$} & $0.03^{\star \star \star}$ & {$[0.02-0.03]$} & $0.06^{\star \star \star}$ & {$[0.05-0.07]$} & $0.03^{\star \star \star}$ & {$[0.03-0.04]$} \\
\hline
\end{tabular}

maintenance and management of the household, travel and time for public provisioning and care) in all sectors (rural and urban). In a country like India, the dominance of unpaid work has been observed because the increasing market economy has failed to recognize the existence of unpaid work, which is further aggravated by the non-fulfillment of the essential provisionings and poor implementation of welfare schemes by the state. 


\section{Assessment of the relative contributions of factors affecting women in domestic duties}

Considering the magnitude and distribution patterns of women engaged in unpaid domestic activities across several socioeconomic determinants, it is indispensable to comprehend the degree to which each of these determinants has influenced the domestic work status of women in different phases. To capture the combined effects of these determinants, the dynamics of the work status of women (unpaid domestic work) over time have been explored (Table 5) by applying logistic regression, which is useful to predict the likelihood of women's work status related to unpaid domestic work. It has been observed that the engagement of urban women in unpaid domestic work is 37 percent higher than that of their rural counterparts in 2012. However, these rural-urban differences have declined over the period. The inordinate burden of domestic work has increased in urban areas owing to consistent dropping out of jobs. While examining the contribution of the age group, it has been observed that, women belong to the age group 15-24 and 60+ have shown higher probability of being engaged in unpaid domestic activities compared to women of any other age group. The existing literature advocates that the increasing level of education among women will augment their participation in the paid work activities (Beneria and Sen, 1982; Goldin, 1994; Mammen and Paxson, 2000). However, this study divulges that there is a disproportionate share of unpaid domestic work and educational status of women.

Women with educational level less than intermediary are more vulnerable to be engaged in unpaid domestic work. There is a clear mismatch between skills accrued through formal education and skills required for getting a decent job in the labor market; hence, women have to perform unpaid domestic duties (Singh and Pattanaik, 2019). Likewise, technical education plays a significant role in the work status of women, and women with no technical education have higher (four times) probability to be engaged in unpaid domestic work compared to women having any form of technical education.

While examining social status, it has been observed that women belonging to $\mathrm{OBC}$ and other categories have higher (two times) likelihood to be engaged in unpaid domestic work compared to women belonging to SC and ST. However, it has been observed that owing to the strict social norms, Muslim women are more likely to be engaged as an unpaid domestic worker compared to women of other religions.

Furthermore, the occupational status and level of income of the household seem to be a major deciding factor for the work status of women. The economic growth has an inversely proportional relationship with unpaid domestic duty. Both land size and income level determine the economic standard of the household. It means that with increase in the household income, women are more likely to involve in unpaid domestic duty. However, it would be short-run, but the scenario can change in the long-run. It has been observed that the likelihood to be engaged in unpaid domestic work is higher among women belongs to richer wealth quintile. Hence, from the results, it is evident that the income of the household is more important for women to demand paid work and exit from unpaid domestic work (Singh and Pattanaik, 2019). Further, the study evaluates the concurrence in land size and domestic duty and observed that the increase in the landholding size of the household, increases the likelihood of unpaid activities among women. However, the likelihood of women to be engaged in unpaid domestic worker is higher by 62 percent in self-employed household as compare to regular wage earner in 2012. Furthermore, the increase in unpaid activities is more intense in different regions owing to the imbalance of socioeconomic characteristics. Hence, women of the eastern region (four times) have higher likelihood of getting engaged in domestic duties followed by women of the central region (three times) in 2011-12, and similar trend is followed throughout the study period. Thus, the findings of this section have to be apprehended holistically from the point of view of vulnerability and well-being of women. The intensity of being engaged in domestic work is high among women with low education and those belonging to the lower wealth quintile in society. Further, dichotomies have also been observed, as the intensity of being engaged in domestic work among women is high among the high social class and households having high land holdings and well-established employment status. Thus, the fundamental discourse on unpaid domestic work in India is based on the intermixed role of 'Three R' approach-redistribution, recognition, and reduction.

\section{Conclusion}

The focus of this study is two-fold-one is to examine the magnitude and time distribution patterns of women engaged in unpaid domestic activities, and the other is to explore the factors affecting women work status as an unpaid domestic worker. The nature of women's work has endured substantial alterations in the neo-liberal paradigm of Indian economy. The market orientation and withdrawal of state (declining investments in public provisioning) have adversely affected the lives and livelihood of women in India. The magnitude of unpaid domestic work has become even more arduous because Indian economy has neither been able to recognize nor able to reduce and redistribute unpaid domestic work in the society. The disproportionate share of domestic work among women is linked to the lack of access to paid employment and women's low status (in terms of education and wealth) in society. From the Indian perspective, a significant number of women are engaged in unpaid domestic work because of three factors-Constraints (social and religious), Choices (failure of market and states to provide essential provisioning), and Career (low opportunity cost of unpaid work in the market). The 'Three R' approach toward unpaid domestic work should be considered for changing the work status of women (from Unpaid to Paid) in the economy, which will reduce the unpaid work among women. Hence, we are propositioning that by removing Constraints (social-stigmas and religious norms), creating better Choices (making market and states to provide essential provisioning, so that women can make a choice), and generating Career (better opportunity cost of unpaid work in the market), we will be able to change the economic status of women from Unpaid to Paid following the "Three R" approach (Reward, Recognition, and Reduction). Therefore, to achieve a more egalitarian economy for women, efforts have to be made holistically within the broader context of household, state, market, and society through macro, meso, and micro interconnections from several fronts, i.e., paradigm shift in social norms to change the status of women, increase educational status of women and girls, investment made by the state for essential public provisioning, and encourage job market.

\section{Data availability}

The datasets generated and/or analyzed during the current study are available in the Ministry of Statistics and Program Implementation, Government of India at National Data Archive, an online microdata repository, http://microdata.gov.in/nada43/ index.php/catalog/central. For data access, registration with the website is the first step. All the steps of data access are elaborated in the following link http://microdata.gov.in/nada43/index.php/ catalog/central. 
Received: 28 September 2019; Accepted: 28 April 2020;

Published online: 04 June 2020

\section{References}

Census (2011) Census of India 2011. Provisional population totals. Government of India, New Delhi

NSSO (1997) Participation of Indian women in household work and other specified activities July 1993-June 1994. National Sample Survey Organisation 50th round, Report No. 416. Ministry of Statistics and Programme Implementation, Government of India, New Delhi

Addati L, Cattaneo U, Esquivel V, Valarino I (2018) Care work and care jobs for the future of decent work. International Labor Organization, Geneva

Aguirre D, Hoteit L, Rupp C, Sabbagh K (2012) Empowering the third billion: women and the world of work in 2012. Booz and Company, New York

Allendorf K (2012) Women's agency and the quality of family relationships in India. Popul Res Policy Rev 31(2):187-206

GoI (1974) Towards equality: report of the committee on the status of women in India. Ministry of Education and Social Welfare, Government of India, New Delhi

NSSO (2000) Employment and unemployment in India July 1999-June 2000. National Sample Survey Organisation 55th Round, Report No. 455(55/10/1). Ministry of Statistics and Programme Implementation, Government of India, New Delhi

NSSO (2007) Participation of women in specified activities along with domestic duties, July 2004-June 2005. National Sample Survey Organisation 61st Round, Report No. 518(61/10/4). Ministry of Statistics and Programme Implementation, Government of India, New Delhi

IMF (2013) Women, work, and the economy: macro-economic gains from gender equity. IMF Staff Discussion Note. International Monetary Fund, Washington

NSSO (2014) Participation of women in specified activities along with domestic duties, July 2011-June 2012. National Sample Survey Organisation 68th Round, Report No. 559(68/10/3). Ministry of Statistics and Programme Implementation, Government of India, New Delhi

Amott TL, Matthaei JA (1996) Race, gender, and work: a multi-cultural economic history of women in the United States. South End Press

Antonopoulos R (2009) The unpaid care work-paid work connection. International Labor Office (ILO), Policy integration and Statistics Department, Geneva

Antonopoulos R, Hirway I (eds) (2010) Unpaid work and the economy - gender, time use and poverty in developing countries. Palgrave Macmillan, London

Banerjee R, Gupta ND, Villeval MC (2018) The spillover effects of affirmative action on competitiveness and unethical behavior. Eur Econ Rev 101:567-604

Baquié S, Urpelainen J (2017) Access to modern fuels and satisfaction with cooking arrangements: survey evidence from rural India. Energy Sustain Dev 38:34-47

Becker GS (1965) A theory of the allocation of time. Econ J 75(229):493-517

Beneria L, Sen G (1982) Class and gender inequalities and women's role in economic development: Theoretical and practical implications. Feminist Studies $8(1): 157-176$

Benston M (1969) The political economy of women's liberation. Mon Rev 21 (4):13-27

Bhatt E (1988) Shramshakti: National Commission on Self employed Women and Women in the Informal Sector. Department of Women \& Child Development Government of India, New Delhi

Budlender D (2004) Why should we care about unpaid care work? Southern Africa Regional Office

Budlender D (eds) (2010) What do time use studies tell us about unpaid care work? Evidence from seven countries. In: Time use studies and unpaid care work. Routledge, London

Cerrutti M (2000) Economic reform, structural adjustment and female labor force participation in Buenos Aires, Argentina. World Dev 28(5):879-891

Chakravarti U (1993) Conceptualising brahmanical patriarchy in early India: gender, caste, class and state. Econ Political Wkly 28(14):579-585

Cooper LB, Paluck EL, Fletcher EK, Ryan IM, Branscombe NR, Center TJ (2013) Reducing gender-based violence. The Sage handbook of gender and psychology. Sage Publication

Cott NF (1997) The bonds of womanhood: woman's sphere in new England 1780-1835. Falling Wall Press Bristol, Bristo

Crow B, McPike J (2009) How the drudgery of getting water shapes women's lives in low-income urban communities. Gend Technol Dev 13(1):43-68

Dalla Costa M, James S (1975) The power of women and the subversion of the community. IMF working paper WP/15/55. Asia and Pacific Department, Washington

Das MS, Jain-Chandra S, Kochhar MK, Kumar N (2015) Women workers in India: why so few among so many? International Monetary Fund, Washington

Das MB (2006) Do traditional axes of exclusion affect labor market outcomes in India?. Social Development Papers No 97. South Asia series World Bank. Washington DC
Dong XY, An X (2015) Gender patterns and value of unpaid care work: findings from China's first large-scale time use survey. Rev Income Wealth 61(3):540-560

Dubbert JL (1979) A man's place: masculinity in transition. The University of Virginia, Prentice Hall

Dube S (1998) In the land of poverty: memoirs of an Indian family: 1947-97. Zed Books, London

Elson D (1999) Labor markets as gendered institutions: equality, efficiency and empowerment issues. World Dev 27(3):611-627

Elson D (2017) Recognize, Reduce, and Redistribute Unpaid Care Work: How to Close the Gender Gap. New Labor Forum 26(2):52-61

Esquivel V, Budlender D, Folbre N, Hirway I (2008) Explorations: time-use surveys in the south. Fem Econ 14(3):107-152

Eswaran M, Ramaswami B, Wadhwa W (2013) Status, caste, and the time allocation of women in rural India. Econ Dev Cult Change 61(2):311-333

Fletcher E, Pande R, Moore CM (2017) Women and work in india: descriptive evidence and a review of potential policies. HKS working paper no. RWP18-004. Center for International Development Harvard University, Cambridge

Folbre N, Yoon J (2008) Economic development and time devoted to direct unpaid care Activities. UNRISD Flagship Report on Poverty. United Nations Research Institute for Social Development, Geneva

Fraser N (2001) Recognition without ethics? Theory Cult Soc 18(2-3):21-42

Gardiner J, Himmelweit S, Mackintosh M (1975) Women's domestic labor. New Left Rev 89(1):47-58

Gilman CP (1998) Women and Economics: A Study of the Economic Relation Between Men and Women as a Factor in Social Evolution. University of California Press, Berkeley

Goldin C (1994) The U-shaped female labor force function in economic development and economic history. National Bureau of Economic Research working paper no. 4707. Cambridge

Government of India (2015) Report of the Sub-Committee on System of Indian National Accounts. Ministry of Statistics \& Programme Implementation, Government of India, New Delhi

Grimshaw D, Rubery J (2015) The motherhood pay gap. Working paper no. 1/ 2015. International Labor Organization, Geneva

Harrison J (1973) The political economy of housework. Bulletin of the Conference of Socialist Economists 3(3):35-52

Hartmann H (1976) Capitalism, patriarchy, and job segregation by sex. Signs (Chic) 1(3/2):137-169

Hirway I (2015) Unpaid work and the economy: linkages and their implications. Indian J Labor Econ 58(1):1-21

Hirway I (2005) Unpaid work and economy: gender, poverty and millennium development goals. Integrating unpaid work into development policy working paper no. 838. Hudson

Jain D (1996) Valuing work: time as a measure. Econ Polit Wkly 31(43):46-57

Jain S (2006) Women's agency in the context of family networks in Indian diaspora. Econ Polit Wkly 41(23):2312-2316

Kabeer N (1994) Reversed realities: gender hierarchies in development thought Verso Books, London

Kabeer N (2008) Mainstreaming gender in social protection for the informal economy. Commonwealth Secretariat, London

Kabeer N (2012) Women's economic empowerment and inclusive growth: labor markets and enterprise development. Int Dev Res Cent 44(10):1-70

Kambhampati US (2009) Child schooling and work decisions in India: the role of household and regional gender equity. Fem Econ 15(4):77-112

Kessler-Harris A (1987) Equal employment opportunity commission v. Sears, Roebuck and company: a personal account. Fem Econ 25(1):46-69

Kingdon GG (1998) Does the labor market explain lower female schooling in India? J Dev Stud 35(1):39-65

Kuznets S (1948) National income: a new version. Rev Econ Stat 30(3):151-179

Maloney WF (2004) Informality revisited. World Dev 32(7):1159-1178

Mammen K, Paxson C (2000) Women's work and economic development. J Econ Perspect 14(4):141-164

Marphatia AA, Moussié R (2013) A question of gender justice: exploring the linkages between women's unpaid care work, education, and gender equality. Int J Educ Dev 33(6):585-594

Matthaei J (2001) Healing ourselves, healing our economy: paid work, unpaid work, and the next stage of feminist economic transformation. Rev Radic Polit Econ 33(4):461-494

McMullin JA (2005) Patterns of paid and unpaid work: the influence of power, social context, and family background. Can J Aging 24(3):225-236

Mehrotra S, Gandhi A, Sahoo BK, Saha P (2012) Creating employment in the twelfth five-year plan. Econ Polit Wkly 47(19):63-73

Mehrotra S, Parida J, Sinha S, Gandhi A (2014) Explaining employment trends in the Indian economy: 1993-94 to 2011-12. Econ Polit Wkly 49(32):49-57

Mincer J (1962) Labor force participation of married women: a study of labor supply. In aspects of labor economics. Princeton University Press, New Jersey, pp. 63-105 
Nagbrahmam D, Sambrani S (1983) Women's drudgery in firewood collection. Econ Polit Wkly 18(1/2):33-38

Neetha N (2010) Estimating unpaid care work: methodological issues in time use surveys. Econ Polit Wkly 45(44):73-80

Neff DF, Sen K, Kling V (2012) The puzzling decline in rural women's labor force participation in India: a reexamination. Working paper no. 196. GIGA German Institute of Global and Area Studies, Hamburg

Oakley A (1974) Housewife. Martin Robertson Penguin, London

Omvedt G (1987) The origin of patriarchy. Econ Polit Wkly 22(44):70-72

Palriwala R, Neetha N (2011) Stratified familialism: the care regime in India through the lens of childcare. Dev Change 42(4):1049-1078

Pande R (2018) The history of feminism and doing gender in india. Estud Fem 26 (3):1-17

Patel SJ, Patel MD, Patel JH, Patel AS, Gelani RN (2016) Role of women gender in livestock sector: a review. J Livest Sci 7:92-96

Razavi S (2007) The political and social economy of care in a development context: Conceptual issues, research questions and policy options (3). United Nations Research Institute for Social Development Geneva, Switzerland

Schultz TP (1990) Women's changing participation in the labor force: a world perspective. Econ Dev Cult Change 38(3):457-488

Sengupta S (2019) Paid-unpaid work continuum of women: home-based workers and self-employed women in the national capital region. Indian J Labor Econ 62(2):265-278

Shiva V (1991) The violence of the green revolution: third world agriculture, ecology and politics. IICA, México

Singh P, Pattanaik F (2019) Economic status of women in India: paradox of paid-unpaid work and poverty. Int J Soc Econ 46(3):410-428

Singh P, Pattanaik F (2020) Unequal reward for equal work? Understanding women's work and wage discrimination in india through the meniscus of social hierarchy. Contemporary Voice of Dalit 12(1):19-36

SNA (1993) System of National Accounts, vol. 2. Inter-Secretariat Working Group on National Accounts \& Commission of the European Communities, Washington

Williams J (2001) Unbending gender: why family and work conflict and what to do about it. Oxford University Press, Oxford

\section{Author contributions}

Both authors contributed equally to this work.

\section{Competing interests}

The authors declare no competing interests.

\section{Additional information}

Supplementary information is available for this paper at https://doi.org/10.1057/s41599020-0488-2.

Correspondence and requests for materials should be addressed to P.S.

Reprints and permission information is available at http://www.nature.com/reprints

Publisher's note Springer Nature remains neutral with regard to jurisdictional claims in published maps and institutional affiliations.

(c) (i) Open Access This article is licensed under a Creative Commons Attribution 4.0 International License, which permits use, sharing, adaptation, distribution and reproduction in any medium or format, as long as you give appropriate credit to the original author(s) and the source, provide a link to the Creative Commons license, and indicate if changes were made. The images or other third party material in this article are included in the article's Creative Commons license, unless indicated otherwise in a credit line to the material. If material is not included in the article's Creative Commons license and your intended use is not permitted by statutory regulation or exceeds the permitted use, you will need to obtain permission directly from the copyright holder. To view a copy of this license, visit http://creativecommons.org/ licenses/by/4.0/.

(C) The Author(s) 2020 